\title{
Atypical Chemokine Receptor 3
}

National Cancer Institute

\section{Source}

National Cancer Institute. Atypical Chemokine Receptor 3. NCI Thesaurus. Code $C 91371$.

Atypical chemokine receptor 3 (362 aa, $\sim 41 \mathrm{kDa}$ ) is encoded by the human ACKR3 gene.

This protein is involved in the negative regulation of chemokine signaling. 